\title{
TEACHING REFUSAL STRATEGIES IN THE FOREIGN LANGUAGE CLASSROOM: A FOCUS ON INDUCTIVE-DEDUCTIVE TREATMENTS
}

\author{
Alicia Martínez-Flor \\ Vicente Beltrán-Palanques \\ University Jaime I (Castellón)
}

\begin{abstract}
The present paper attempts to present a pedagogical model for the integration of pragmatic competence in the foreign language classroom by following an inductive-deductive approach. For the sake of the current article, the pragmatic feature that has been chosen is the speech act of refusals. The rationale behind this selection is based on the fact that refusals are seen as a face-threatening act which may confront listeners' expectations (Eslami 2010: 217). Hence, learners should obtain a particular pragmatic expertise to outperform refusals successfully and that is the reason why the teaching of this speech act should be integrated in foreign language settings.
\end{abstract}

Keywords: Pragmatic competence, instruction, inductive-deductive approach, speech acts, refusals, foreign language classroom. 


\title{
INSTRUCCIÓN DE ESTRATEGIAS DE RECHAZO EN EL AULA DE LENGUA EXTRANJERA CENTRADO EN TRATAMIENTOS INDUCTIVOS Y DEDUCTIVOS
}

\begin{abstract}
RESUMEN. El siguiente trabajo presenta una propuesta pedagógica siguiendo un enfoque inductivo-deductivo cuyo objetivo es fomentar la competencia pragmática en el aula de lenguas extrajeras. En este caso en particular, el aspecto pragmático elegido es el acto de habla del rechazo. Dicha selección se basa en el hecho de que el acto de habla del rechazo puede confrontar las expectaciones del otro interlocutor (Eslami 2010: 217). Por esto, los aprendices deben obtener un cierto nivel de competencia pragmática para poder refutar de manera apropiada y por lo tanto es necesario integrar este acto de habla en contextos de lenguas extranjeras.
\end{abstract}

Palabras clave: competencia pragmática, instrucción, enfoque inductivodeductivo, actos de habla, rechazos, aula de lenguas extranjeras.

Received 15 March 2013

Revised version accepted 30 June 2013

\section{INTRODUCTION}

In order to communicate accurately in a given second/foreign language (SL/FL) learners should master not only grammatical aspects of the target language, but also pragmatic aspects (Usó-Juan and Martínez-Flor 2006: 15-19). Particularly, learners are expected to acquire a specific pragmatic competence which allows them to succeed in their social interactions. This specific competence can be defined as the ability to use and understand language appropriately in different social interactions (Crystal 1997: 301). It has been highlighted that developing learners' pragmatic competence in the target language is crucial since they might be able to succeed in communication (CelceMurcia, Dörnyei and Thurrell 1995: 5-35; Usó-Juan and Martínez-Flor 2006: 3-25). For this particular reason, it seems necessary for learners to achieve a particular command of pragmatic expertise to interact successfully. Reaching to that end, however, appears to be rather complex unless accurate language teaching practises are appropriately implemented (see Martínez-Flor and Usó-Juan 2010a: 423-442; 2010b: 3-20 for a review).

Considering the aforementioned aspects, the present paper attempts to present a pedagogical model for the integration of pragmatic competence in the FL context by following a deductive-inductive approach. For the sake of the current article, the instructional pragmatic feature that has been selected is the speech act of refusals based on the fact that refusals are seen as a face- 
threatening act which may confront listeners' expectations (Eslami 2010: 217). Hence, learners should obtain a particular pragmatic expertise to outperform refusals successfully and that is the reason why the teaching of this speech act should be integrated in formal instructed settings.

\section{THEORETICAL BACKGROUND}

\subsection{TEACHING PRAGMATIC COMPETENCE: INDUCTIVE-DEDUCTIVE APPROACHES}

It has been suggested that developing learners' pragmatic competence should be incorporated in the instructed setting, especially in FL contexts where the opportunities for being exposed to the target language and employing it purposefully are rather limited (Martínez-Flor 2007: 245). It seems that the context in which the target language is acquired might have an effect on the quantity and quality of input to which learners might be exposed to as well as on the type of output produced (Barron 2003: 57). On this account, research has shown that traditional materials such as English language textbooks do not include sufficient pragmatic input (Boxer and Pickering 1995: 44-58; UsóJuan 2007: 223-243; 2008: 65-90; Yagiz 2009: 217-225; Martínez-Flor and Usó-Juan 2010a: 424-427; Beltrán-Palanques 2012a: 125-138) and this particular fact is not exclusively related to the scant number of occurrences but also to the quality of the examples identified (Martínez-Flor and Usó-Juan 2010a: 424-427; BeltránPalanques 2012a: 125-138). In order to overcome this problem, some authors consider that audiovisual material might be useful for providing learners with more contextualised examples of language (Grant and Starks 2001: 39-50; Alcón 2005: 417-475; Martínez-Flor 2007: 245-280; Martínez-Flor and Usó-Juan 2010a: 427-429; 2010b: 11-12; Beltrán-Palanques 2011: 70-84; Mohammad, Alireza and Shirin 2013: 49-63).

Apart from the quantity and quality of the pragmatic input that might be presented to language learners, other aspects such as output opportunities and feedback on performance should also be taken into account (Martínez-Flor and Usó-Juan 2010b: 12-15). In line with this, several instructional approaches have been developed so as to help language teachers to integrate speech acts in the language classroom (see for example Félix-Brasdefer 2006: 165-197; Martínez-Flor and Usó-Juan 2010c: 3-274; Beltrán-Palanques 2012b: 85-100). Broadly speaking, researchers developing speech act instructional approaches consider that language learners should be provided with (1) input which should be rich and contextualised; (2) appropriate communicative and purposeful activities; and (3) feedback on language use. The integration of pragmatics in 
instructed settings has therefore been typically designed by adopting two types of pedagogical treatments, namely those of explicit and implicit instruction (Tateyama, Kasper, Mui, Tay and Thananart 1997: 163-177; Fukuya and Zhang 2002: 1-47; Alcón 2005: 417-475; Fordyce 2013: 1-24). On the one hand, explicit teaching involves directing learners' attention towards the target forms with the aim of discussing those forms (Doughty 2003: 265). In contrast, an implicit pedagogical approach aims to attract learner's attention while avoiding any type of metalinguistic explanation and minimising the interruption of the communicative situation. Thus, the main difference between the two types of instruction concerns the provision or absence of rules. However, given the fact that these two types of treatments have been the most commonly employed in interventional pragmatic studies, Kasper and Roever (2005: 323-324) argue for the need to conduct more research adopting other types of interventional approaches, such as inductive and deductive treatments. Following DeKeyser (2003: 314), we can get a detailed description of what inductive and deductive teaching approaches involve by understanding their relationship with the explicit-implicit dichotomy previously explained (see Table 1).

Table 1. The inductive/deductive and implicit/explicit dimensions (DeKeyser, 2003: 314).

\begin{tabular}{|c|c|c|}
\hline & Deductive & Inductive \\
\hline Explicit & Traditional teaching & Rule discovery \\
\hline Implicit & Using parameters & Learning L1 from input \\
\hline
\end{tabular}

Hence, according to DeKeyser (2003: 314), explicit learning can be done both (1) deductively following either an explicit approach which involves traditional teaching or an implicit approach by using specific parameters; and (2) inductively by adopting either an explicit perspective, thereby based on rule discovery, or from an implicit one by learning L1 from input. Considering those aspects, DeKeyser (2003: 335) argues that the combination of implicit and inductive is clear-cut if we think of children acquiring their first language as they are not aware of this particular process. Nonetheless, the author also states that the categories of implicit and deductive learning are not always evident. For the sake of this study, the distinction presented by DeKeyser (2003: 314) is considered in its application to the learning of pragmatics. Then, we assume that both inductive and deductive teaching approaches are examples of explicit instruction. That is, in an inductive approach to language teaching, learners are not taught rules directly, but are left to discover those rules from various 
examples and their experience of using the language. The deductive approach, on the other hand, provides learners first with a detailed explanation of the rules and then with examples and exercises in which to practise those rules.

As matter of fact, the paradigm of inductive-deductive approaches in pragmatic teaching has called the attention of several researchers (Kubota 1995: 35-67; Shaw and Trosborg 2000: 204-214; Rose and Kwai-fun 2001: 145-170; Martínez-Flor 2008: 191-225, 2012: 243-274; Takimoto 2008a: 31-51; 2008b: 369386). The study conducted by Kubota (1995: 35-67) explored the ability to understand implicature in English. Participants of this investigation were formed by a group of intermediate Japanese EFL students who were distributed into three different teaching approaches, namely (1) an inductive approach, in which participants worked in groups in order to figure out how implicatures work in English; (2) a teacher-directed deductive approach involving rule explanation, and (3) zero instruction in implicature. Results from the post-test that was administered after the 20-minute treatment indicated that the students who received either deductive or inductive instruction had an advantage over the uninstructed group, and they also showed a greater effect for the inductive approach when both treatment groups were compared.

Rose and Kwai-fun (2001: 145-170) examined the two types of instructional treatments by focusing on the speech acts of compliments and responses to compliments of learners of English in Hong Kong as compared to a control group. The learners' production after having received instruction during six 30minute lesson was measured by means of a self-assessment questionnaire, a metapragmatic assessment questionnaire and a discourse completion test (DCT). Findings from the first two measurement instruments did not reveal differences among the three groups. However, the responses obtained through the DCTs showed that learners who received instruction outperformed those from the control group. Hence, both treatment groups increased their syntactic formulae appropriateness for compliments, even though a positive effect was only found in the deductive group concerning compliment responses. In light of these findings, the authors suggested that both instructional treatments demonstrated effectiveness in the case of pragmalinguistics, whereas only the deductive approach involving metapragmatic discussion proved a positive effect regarding learners' sociopragmatic proficiency.

As reported by Trosborg (2003: 265-267), a similar study to that of Rose and Kwai-fun (2001: 145-170) was conducted by Shaw and Trosborg (2000: 204-214). The focus of this study was to compare the effect of deductive and inductive approaches as regards the speech act of complaints, particularly, a set of telephoned complaints. This investigation involved fifteen students who were 
distributed into two different treatment groups that received three short teaching sessions. On the one hand, the group which received deductive approach was characterised by rule presentation and discussion. On the other hand, the other group was assigned to an inductive approach which involved different activities, such as reading dialogues, watching TV comedies or listening to a model containing the target items and repeating the sentences employed. Results from the comparison of the role-plays employed for the pre-test and post-test indicated that no major differences between the deductive and inductive groups were found. However, the authors reported that the former type of instruction was slightly more effective than the latter.

Considering the results obtained in the studies which examined the effectiveness of the two instructional approaches (Shaw and Trosborg 2000: 204214; Rose and Kwai-fun 2001: 145-170), Trosborg (2003: 269) proposed the use of both of them by including various steps which could activate each type of reasoning, inductive and deductive, in turn. Taking into account Trosborg's (2003: 269) contention towards the combination of both types of approaches, Martínez-Flor's (2008: 191-225) study analysed the effectiveness of an inductivedeductive teaching approach. Specifically, the author explored learners' production of the modification devices that accompany the speech act of requesting in order to mitigate its impositive pragmatic force. The instructional approach adopted was based on Martínez-Flor's (2007: 274-276) study in which the author proposed the use of film excerpts as a source for providing learners with appropriate and contextualised pragmatic input. Participants of this investigation consisted of 38 students of elementary proficiency level. In order to carry out this investigation, both a pre-test and post-test design was followed. The pre-test was administered at the beginning of the semester and four weeks before the treatment started, and the post-test was distributed four weeks after the treatment had finished. Results of this study revealed that, after having participated in the instructional treatment, learners (1) used a greater number of request modifiers, (2) employed a higher number of internal and external modifiers, and (3) made use of different subtypes of internal and external modifiers which meant that learners included a rich variety of mitigating devices in their requestive production.

Focusing also on the speech act of requesting, Takimoto's (2008a: 31-51) study dealt with the effects of various form-focused instruction approaches on learners' ability to both comprehend and produce polite requests. Participants of this study were made up of a total of 60 Japanese learners of English who were assigned to three different groups. Each group received a different instructional approach, specifically (1) deductive instruction; (2) inductive 
instruction with problem-solving tasks; and (3) inductive instruction with structured input tasks. The tasks incorporated explicit input-based instruction and they were designed to test differences across deductive and inductive approaches. In the study, the author employed pre-tests (i.e. two to three days before the instruction), post-tests (i.e. eight to nine days after instruction) and follow-up tests (i.e. in the fourth week following instruction). The tests involved two output-based tests, including an open-ended discourse completion test and a role-play test; and two input-based consisting of a listening test and an acceptability judgement test. Findings revealed that the three treatment groups outperformed the control group, thereby indicating that the explicit input-based instruction was effective in both teaching approaches, that is to say, deductively and inductively. Moreover, Takimoto (2008a: 31) also reported that the inductive treatment might be somehow superior in the long term.

Likewise, Takimoto (2008b: 369-386) conducted a study which attempted to investigate the effects of deductive and inductive teaching approaches. However, differently to Takimoto (2008a: 31-51), the purpose was now to teach learners how to use lexical and phrasal downgraders and syntactic downgraders when performing requests. Participants of this study were 60 Japanese learners of English of intermediate proficiency level and four groups consisting of three treatment groups plus the control group were established. In so doing, in each treatment group the following types of instruction were provided, (1) deductive with explicit input-based instruction; (2) inductive with problem-solving and explicit input-based instruction; and (3) inductive instruction with structured input tasks. Participants of this study completed a pre-test, a post-test as well as a follow-up test. Moreover, each of the different tests involved two receptive judgement tasks and two production tasks. Results indicated that all the three groups appeared to outperform the control group. Nevertheless, regarding the listening test it was identified a reduction in the positive effects of the instructional period between the post-test and follow up test.

More recently, Martínez-Flor (2012: 243-274) conducted a study which explored the long-term effects of pragmatic instruction by following an inductive-deductive teaching approach. The purpose of the treatment was to foster learners' ability to mitigate requests not only concerning the immediate effects of instruction, but also taking into consideration the impact of the instructional period after four months. Participants of this investigation consisted of 22 Spanish learners of English whose proficiency level was upperintermediate. The study involved a pre-test, post-test and a delayed post-test design. Specifically, the participants took a pre-test at the beginning of the semester and four weeks before the starting of the instructional treatment in 
order to examine whether request mitigators were performed. The week after the instructional treatment had finished, the post-test was administered. The situations employed in the latter were the same than the ones used in the pretest. However, the two tests did not follow the same arrangement. Finally, four months after the completion of the post-test, a delayed post-test containing the same arrangement as the pre-test was done. Findings from this study indicated that learners employed a greater number of appropriate request modifiers and that they used all the different subtypes of internal and external modifiers both immediately after receiving the instruction as well as four months later. In light of these results, the author suggested that the positive effects of the treatment might be related to the particular characteristics of the instructional approach being taken, namely those of (1) learners' exposure to authentic-like pragmatic input; (2) the elaboration of different pragmatic-oriented activities (e.g. awareness-raising and communicative activities); (3) the focus on pragmalinguistic and sociopragmatics features; (4) the operationalisation of deductive-inductive approaches; and (5) the duration of the teaching approach (i.e. three two-hour sessions).

Taking into account the findings of the aforementioned studies as regard the effectiveness of using an inductive-deductive approach for the teaching of speech acts, we aim at presenting a particular pedagogical model for its implementation in the FL classroom setting. Before doing so, however, we provide a description of the particular pragmatic aspect being selected as the instructional target feature, namely the speech act of refusals, in the next subsection.

\subsection{THE SPEECH ACT OF REFUSALS}

The speech act of refusals might be seen as one of the most face-threatening speech acts (FTAs) as the use of them might confront the expectations of the other participant involved in the conversation (Esmali 2010: 217). In fact, Beebe, Takahashi and Uliss-Weltz (1995: 56) argue that refusals have been seen as a "major cross-cultural sticking point for many nonnative speakers". It is because their face-threatening nature as well as the lack of acceptance to a particular initiating proposition that they are subjected somehow to breakdowns in communication. Specifically, the speech act of refusal involves a denial of particular proposition initiated by an interlocutor and it might serve as a response to other speech acts such as requests, offers, invitations and suggestions (Gass and Houck 1999: 3). Therefore, a refusal is provided as a response to another speech act which is initiated by another participant and it might threaten the listeners' face. This particular speech act, however, may be performed by means 
of indirect strategies as an attempt to avoid communication failure (Gass and Houck 1999: 7-19; Félix-Brasdefer 2008a: 74-82; 2008b: 196). Moreover, when refusing, several turns can be employed to negotiate refusal strategies in order to reduce the negative impact that they might have on the other interlocutor (Martínez-Flor 2013). However, performing indirect refusals could be seen as a challenge for the speakers as it might necessarily involve the use of various linguistic resources in order to mitigate the negative effect of a refusal (FélixBrasdefer 2008b: 196). Furthermore, it is important to note that the level of directness or indirectness appears to be directly related to the contextual conditions in which such speech act events are uttered. (Beebe, Takahashi and Uliss-Weltz 1990: 57-60). Particularly, the three major aspects to consider when refusing are those proposed by Brown and Levinson (1987: 74) which include social distance, power and rank of imposition. Nevertheless, other aspects such as gender and age might also influence the speakers' refusal behaviour (Fraser 1990; Smith 1998 cited in Wannaruk 2008: 319). In this regard, interlocutors' knowledge of pragmalinguistic, sociopragmatic features and politeness issues play a paramount role when communicating.

In order to describe the different pragmatic realisations that can be used to perform this speech act, several taxonomies have been developed (Beebe, Takahashi and Uliss-Weltz 1990: 55-73; Salazar, Safont and Codina 2009: 139150, among others). One of the pioneering taxonomies and most widely employed to code the speech act of refusals was advanced by Beebe, Takahashi and Uliss-Weltz (1990: 55-73). The authors categorised the different speech act realisations into direct, indirect and adjuncts to refusals. This particular classification was further developed by Gass and Houck (1999: 52) who noted that it should also account for three different responses such as confirmation, request for clarification and agreement The taxonomy proposed by Beebe, Takahashi and Uliss-Weltz (1990: 55-73) was also complemented by FélixBrasdefer (2003: 220-251) who included the category of solidarity politeness strategies. More recently, based on the classification advanced by Beebe, Takahashi and Uliss-Weltz (1990: 55-73) and by adopting a conversational perspective (see Kasper 2006a: 83-99 for a review), Salazar, Safont and Codina (2009: 139-150) presented a taxonomy for the examination of refusal strategies, which is classified into direct and indirect semantic formulas and its adjuncts.

On the one hand, in the group of direct strategies, two main subtypes are considered, namely those of bluntness and negation of proposition. The former refers to the use of a flat no or the performative verb I refuse. The latter entails expressions which imply negations such as I can't or I don't think so. On the other hand, indirect strategies involve seven different types, more specifically: 
(1) plain indirect, which encapsulates the different expressions that can be utilised to mitigate the refusal (e.g. "It looks I won't be able to go"); (2) reason or explanation, in which the speaker explains the reason why the proposition is refused (e.g. "I have a doctor's appointment"); (3) regret or apology, in which the speaker can express that he/she feels bad for declining the proposition (e.g. "I'm so sorry"); (4) alternative, which entails two different subtypes, change opinion in which the speaker can suggest another option (e.g. "I would join you if you choose another restaurant") and change time in which the acceptance of the proposition is postponed (e.g. "I can't go right now, but I could next week"); (5) disagreement/ dissuasion/ criticism, in which the speaker can emphasise the negative effect that a given proposition might have on the other interlocutor (e.g. "Under the current economic circumstances, you should not be asking for a rise right now!"); (6) statement of principle/ philosophy, in which the speaker may resort to moral issues in order to turn down the proposition (e.g. "I can't. It goes against my beliefs!"); and finally (7) avoidance which is made up of non-verbal such as ignoring by means of silence and verbal like hedging (e.g. "Well, I'll see if I can"), change topic, joking, and sarcasm.

Additionally, five main types of adjuncts to refusals are included. Adjuncts, albeit they accompany the refusal strategy they do not constitute the speech act as such. They involve five different subtypes, namely (1) positive opinion, in which the speaker can express that the request is a good idea albeit he/she will not accede to it (e.g. "This is a great idea, but..."); (2) willingness, in which the speaker might refuse the proposition by uttering expressions such as "I'd love to go, but..."; (3) gratitude can be used by the speaker in combination with a refusal to thank the other interlocutor's proposition (e.g. "Thanks so much, but..."); (4) agreement, in which the speaker can express consent before performing the refusal (e.g. "Fine, but..."); and finally (5) solidarity or empathy which can be employed by the speaker to ask the interlocutor for sympathy (e.g. "I'm sure you will understand, but...").

To sum up, the speech act of refusals is one of the most face-threatening speech acts which require a particular level of pragmatic expertise so as to perform them appropriately and succeed in communication. As mentioned above, the level of directness or indirectness may vary according to the contextual factors involved in the social encounter, specifically those of social distance, power and rank of imposition (Levinson and Brown 1987: 74) as well as gender and age (Fraser 1990; Smith 1998 cited in Wannaruk 2008: 319). There is, however, a tendency to employ indirect realisations in order to mitigate the face-threatening aspect and reduce the negative effect that refusals might evoke (Martínez-Flor, 2013). Nevertheless, unless learners achieve sufficient pragmatic 
knowledge involving both knowledge of pragmalinguistics and sociopragmatics, learners might take the risk of breaking the communicative event. In this sense, and although different studies have been conducted to examine the effectiveness of integrating this speech act in instructed settings (see for example Bacelar Da Silva 2003: 55-106; Kondo 2008: 153-177; Martínez-Flor 2011: 357-363), more attention should be given to the teaching of refusals from a communicative perspective and particularly by adopting an inductive-deductive approach. With that in mind, the following section presents a pedagogical model that incorporates these two types of reasoning, namely inductive and deductive, for the integration of the speech act of refusals in the FL classroom.

\section{THE PROPOSED INDUCTIVE-DEDUCTIVE TEACHING APPROACH}

The main aim of the pedagogical model developed in this section is that of making learners reflect on the sociopragmatic aspects that may affect an appropriate use of refusals in the FL and how the pragmalinguistic realisations chosen can influence this performance. Hence, the suggested instructional approach attempts to foster learners' pragmatic competence by tackling with the sociopragmatic (i.e. rules that govern linguistic realisation) and pragmalinguistic (i.e. linguistic resources) features that might affect refusals' performance. In order to design it, three main conditions for the learning of speech acts in instructed settings have been considered, particularly exposure to pertinent input, opportunities for communicative practice and feedback (Martínez-Flor and Usó-Juan 2010b: 10-5). Regarding the type of input selected, we have considered the value of audiovisual input as its use when teaching different speech acts in FL contexts has already been praised in previous investigations (Rose and Kwai-fun 2001: 145-170; Bacelar Da Silva 2003: 55-106; Alcón 2005: 417-475; Martínez-Flor 2008: 191-225; 2012: 243-274). More specifically, we advocate for the use of films as a source for presenting authentic-like instances of contextualised refusals together with practical activities that allow learners to use the refusal strategies being taught in different communicative situations.

The instructional approach proposed below has been adapted from MartínezFlor (2007: 274-275; 2008: 201) and Beltrán-Palanques (2011: 82) and provides two reasoning models (i.e. inductive and deductive) for developing the speech act of refusals in the FL context. Specifically, it involves four different phases which range from language awareness to language production and feedback on performance. The first phase focuses on the pragmalinguistic features of the speech act under study; the second phase deals with the sociopragmatic aspects which might affect language production, thereby how the pragmalinguistic realisation could be determined by the context of interaction; the third phase is devoted to learners' 
pragmatic production, that is to say, the opportunities for output; and finally the fourth phase involves learners' feedback.

\subsection{FIRST PHASE: PRAGMALINGUISTIC AWARENESS}

The first phase (i.e. Pragmalinguistic Awareness) of this instructional approach focuses on the learners' pragmalinguistic awareness (see Figure 1 for a schematic representation of the steps to be followed in this first phase). In order to do so, the teacher should first select two different film scenes (step 1) which represent situations in which the speech act of refusals is at work. Drawing on them, two written situations can be elaborated in order to be later completed by learners (step 2). Specifically, in the inductive reasoning model, learners are provided with the two written situations in which a refusal response is expected to be elicited by them (step 3), and later, the corresponding transcript with the actual speech act should be given (step 4). In so doing, learners compare their own production with the refusal elicited in the film scene. It is important to note that at this stage, any explanation concerning pragmalinguistic forms is provided. After this, learners are involved in the deductive approach. In this case, the teacher explains the use of refusal strategies by showing learners the different forms that this speech act can take (step 5). To do so, the taxonomy proposed by Salazar, Safont and Codina (2009: 139-150) can be employed. Nevertheless, emphasis should be only given to the forms rather than to the use of them since this is the purpose of the second phase.

1. Select two different scenes (see Appendix A).

2. Prepare two written situations which reflect the situations of the chosen scenes Inductive approach:

3. Provide learners with different situations in which they are asked to produce their own response. (see Appendix B).

4. Transcripts are given to learners so that they can reflect on their initial responses and draw some comparisons between what is said in the given examples and their own responses (see Appendix C).

Deductive approach:

5. Teacher's exposition and a whole class discussion about the speech act employed in the given situations, more specifically, that of refusal. Hence, pragmalinguistic aspects of that particular speech act are described (i.e. direct and indirect forms).

Figure 1. First phase: Pragmalinguistic awareness. 


\subsection{SECOND PHASE: SOCIOPRAGMATIC AWARENESS}

The purpose of the second phase, Sociopragmatic Awareness, is to make language learners become aware of the importance of the context and how this might affect pragmalinguistic performance (see Figure 2). In this case, the teacher should visualise the film scenes which are employed in the first phase (step 6). In so doing, learners recall what is done in the previous session. Moreover, the teacher might distribute a worksheet (step 7) which should be completed by learners. Hence, in completing this particular activity, learners are engaged in an inductive learning approach which encourages them to reason and reflect on the various aspects which affect language production. More precisely, sociopragmatic features such as context, participants' role, gender, age, as well as politeness aspects (i.e. social distance, power, and rank of imposition) are considered. Having performed this individual activity, learners should be divided into small groups in order to compare their responses. After this, the teacher prepares an exposition in which the topic of sociopragmatics is tackled (step 8). By doing so, learners are engaged in a whole class discussion as an attempt to comment and justify the responses given in the worksheet. Then, the teacher should provide further information about the appropriate use of refusal strategies according to the sociopragmatic features involved in each situation.

6. Present and visualise the two different scenes.

Inductive approach:

7. Provide learners with a worksheet in which they can reflect on the situational context, the relationship between the participants, the social distance and the rank of imposition Transcripts are given to learners so that they can reflect on their initial responses and draw some comparisons between what is said in the given examples and their own responses (see Appendix D).

Deductive approach:

8. Teacher's exposition and a whole class discussion in order to tackle sociopragmatic features.

Figure 2. Second phase: Sociopragmatic awareness.

\subsection{THIRD PHASE: PRAGMATIC PRODUCTION}

Once learners have become familiar with the basic pragmalinguistic realisations and how the sociopragmatics condition might affect language use, they are ready 
to work on the third phase, that of Pragmatic Production (see Figure 3). In this particular phase, learners are encouraged to participate actively in order to put into practise the aspects covered in the two previous phases. Specifically, the teacher selects two new film scenes (step 9) and, without showing them to the students, elaborates a set of role-play activities which reflect the similar situations to those appearing in the audiovisual source (step 10). Learners are provided with sufficient contextual information about the scenarios in order to prepare and perform the role-play activities. These role-plays are acted out only in front of the teacher and after the completion of each one, learners should be involved in a short oral interview with the teacher (step 11). This particular interview, which can be done in the form of retrospective verbal reports, might serve to obtain information concerning learners' pragmatic performance. After this, the teacher initiates a discussion with each pair in order to comment on the pragmalinguistic forms and sociopragmatic features involved in the performed role-plays. Then, the teacher also visualises the different scenes and encourages each pair to compare their realisations with the actual ones and discuss the different sociopragmatic aspects that influence language use (step 13). Hence, in order to better help learners to understand the appropriate use of refusal strategies, steps 11, 12 and 13 are made with the teacher rather than with the whole group in the language classroom.

9. Choose two different scenes (see Appendix E).

Inductive approach:

10. Organise role-play activities reflecting similar situations as those selected.

11. After performing the role-play activities, learners respond to a short oral interview (see Appendix F).

Deductive approach:

12. Initiate a discussion about each pair's performance in which the focus is pragmalinguistic forms and sociopragmatic features involved in its roleplay acted out.

13. Present the selected scenes to each pair in order to establish some comparisons between their own production and that shown in the extracts.

Figure 3. Third phase: Pragmatic production.

\subsection{FOURTH PHASE: FEEDBACK ON PRAGMATIC PRODUCTION}

Having dealt with the previous communicative activities, learners move to the fourth and final phase of the approach, that of Feedback on pragmatic 
production (see Figure 4), in which they receive feedback from the teacher and their peers. To do so, learners are given opportunities to examine critically from a pragmatic approach their spoken production. Learners are involved in a process of inductive feedback (i.e. example-based) in which they first pay attention to their own performance (step 14). Once they have commented the aspects observed in their data, the teacher provides further feedback related to their own production from a rule-based approach, that is to say, deductively (step 15) and organises individual meetings with learners in order to provide individualised feedback (step 16).

Inductive approach:

14. Have a class discussion with feedback on their production in order to make them reflect on the use and the variety of refusal strategies.

Deductive approach:

15. The teacher clarifies doubts related to learners' production of refusal strategies by focusing on the rules that govern speech act performance.

16. Individual feedback in order to explore learners' pragmatic realisation by paying attention to their pragmalinguistic choice and their perception of the sociopragmatic factors that affect such a choice.

Figure 4. Fourth phase: Feedback on pragmatic production.

The above described instructional approach suggests a set of phases which could be followed in order to integrate the speech act of refusals by adopting two types of reasoning, namely inductive and deductive, and it presents activities which range from language awareness to language production. In this model, in an attempt to provide learners with authentic examples, audiovisual input is employed to present learners with contextualised situations in which refusals are performed. The awareness-raising activities focus first on the pragmalinguistic features of the speech act of refusals while the second set of activities explores the sociopragmatic aspects that affect pragmatic production. Concerning the language production activities, learners are given opportunities to perform refusals in a communicative and purposefully way in different contextualised situations. The last phase involves feedback on performance not only from the teacher but also from peers as we consider that collaboration between equals should be fostered in the language classroom. Finally, it is worth pointing out that this instructional approach might serve to integrate the speech act of refusals in the language classroom from a discursive perspective as it 
focuses on the production of speech act sequences through social interaction (see Kasper 2006b: 281-314; González-Lloret 2010: 57-73 for a review). Thereby, attention is paid not only to the performance of single utterances, but also to the sequences which are involved when communicating and negotiating speech act events.

\section{FINAL REMARKS}

The present paper has suggested a particular inductive-deductive instructional approach for the integration of the speech act of refusals in the FL classroom. The proposed approach has considered providing learners with the three necessary conditions for pragmatics learning, namely exposure to appropriate and contextualised input, opportunities for communicative practice as well as feedback on their refusal performance. Specifically, it consists of four different phases in which inductive and deductive types of reasoning have been activated in turn. The purpose of the first phase is to develop learners' awareness of the pragmalinguistic realisations that can be employed when refusing. The focus of the second phase is to raise learners' awareness of sociopragmatic issues (i.e. social distance, power, rank of imposition, gender and age) and how these aspects influence an appropriate language use. In order to implement the aforementioned phases, audiovisual input has been selected due to its potential when integrating speech acts in the FL classroom. The third phase provides communicative activities (i.e. role-plays) in which learners have the opportunity to put into practice the knowledge acquired in the previous phases. Finally, the aim of the last phase is to offer feedback on learners' performance when making refusals in different communicative situations.

Summarising, the proposed instructional approach tries to incorporate the aforementioned activities to help language learners develop their pragmatic expertise. Thereby, in designing them, special attention has been paid not only to the pragmalinguistic features that are available for learners, but also, to the sociopragmatic conditions which might affect an appropriate use of language. In fact, developing learners' pragmatic expertise is seen as one of the most important aspects to be taken into account when teaching a given FL/SL in order to help them communicate successfully in the target language, avoid communication breakdowns or make learners appear rude or uncooperative. Moreover, we consider that it is teachers' responsibility to engage learners in a pedagogical instructional model, such as the one presented in this paper, which raises their awareness of the politeness and sociocultural aspects that may affect communication. Indeed, the value of the approach here suggested lies on the fact 
that any language teacher could adapt it by integrating other pragmatic aspects (i.e. other speech acts, implicature or pragmatic formulas) to meet the particular needs of his/her group of learners. By so doing, learners will have more chances of becoming better communicators in a SL/FL.

\section{REFERENCES}

Alcón, E. 2005 "Does instruction work for learning pragmatics in the EFL context?". System 33: 417-475.

Bacelar da Silva, A. J. 2003. "The effects of instruction on pragmatic development: teaching polite refusals in English". Second Language Studies 22 (1): 55-106.

Barron, A. 2003. Acquisition in Interlanguage Pragmatics: Learning How to Do Things with Words. Amsterdam: John Benjamins.

Beebe, L., Takahashi, T. and R. Uliss-Weltz. 1990. "Pragmatic Transfer in ESL Refusals“. Developing Communicative Competence in a Second Language. Eds. R. C. Scarcella, E. S. Anderson and S. D. Krashen. New York: Newbury House. 55-73.

Beltran-Palanques, V. 2011. "Analysing refusals in films". Current Trends in Anglophone Studies: Cultural, Linguistic and Literary Research. Eds. J. Ruano, M. J. Fernández, M. Borham, M. J. Díez, S. Bautista, P. Álvarez and B. García. Salamanca: Ediciones Universidad de Salamanca. 70-84.

Beltrán-Palanques, V. 2012a. "Examining refusals in ELT textbook: A focus on transcripts”. Interlingüistica 22: 125-138.

Beltrán-Palanques, V. 2012b. "Integrating the speech act of refusals in the instructed setting”. BABEL a.f.i.a.l. 21: 85-100.

Boxer, D. and L. Pickering. 1995. "Problems in the presentation of speech acts in ELT materials: The case of complaints". ELT Journal 49 (1): 44-58.

Brown, P. and S. C. Levinson. 1987. Universals in Language Usage: Politeness Phenomena. Cambridge: Cambridge University Press.

Celce-Murcia M., Dörnyei, Z. and S. Thurrell. 1995. "A pedagogical framework for communicative competence: A Pedagogically motivated model with content specifications". Issues in Applied Linguistics 6: 5-35.

Crystal, D. 1997. The Cambridge Encyclopedia of Language. (2 ${ }^{\text {nd }}$ Edition). Cambridge: Cambridge University Press. 
DeKeyser, R. 2003. "Implicit and Explicit Learning". The Handbook of Second Language Acquisition. Eds. C. Doughty and M. Long. Oxford: Blackwell. 313348.

Doughty, C. 2003. "Instructed SLA: Constrains, compensations, and enhancement". The Handbook of Second Language Acquisition. Eds. C. Doughty and M. Long. Oxford: Blackwell. 256-310.

Eslami, Z. 2010. "Refusals: How to develop appropriate refusal strategies". Speech Act Performance: Theoretical, Empirical and Methodological Issues. Eds. A. Martínez-Flor and E. Usó-Juan. Amsterdam: John Benjamins. 217-236.

Félix-Brasdefer, J. C. 2003. "Declining an invitation: A cross-cultural study of pragmatic strategies in American English and Latin American Spanish". Multilingua 22: 225-255.

Félix-Brasdefer, J. C. 2006. "Teaching the negotiation of multi-turn speech acts. Using conversation-analytic tools to teach pragmatics in the classroom". Pragmatics and Language Learning 11: 165-197.

Félix-Brasdefer, J. C. 2008a. Politeness in Mexico and the United States: A Contrastive Study of the Realization and Perception of Refusals. Amsterdam: John Benjamins.

Félix-Brasdefer, J. C. 2008b. "Perceptions of refusals to invitations: Exploring the minds of foreign language learners". Language Awareness 17 (3): 195-211.

Fraser, B. 1990. "Perspectives on politeness". Journal of Pragmatics 4: 219-236.

Fordyce, K. 2013. "The differential effect of explicit and implicit instruction on EFL learners' use of epistemic stance”. Applied Linguistics 35(1): 6-28.

Fukuya, Y. J. and Y. Zhang, 2002. "The effects of recasts on EFL learners' acquisition of pragmalinguistic conventions of request". Second Language Studies 21(1): $1-47$.

Gass, S. M. and N. Houck, 1999. Interlanguage Refusals: A Cross-Cultural Study of Japanese -English. Berlin: Mouton de Gruyter.

Grant, L. and D. Starks, 2001. "Screening Appropriate Teaching Materials. Closing from Textbooks and Television Soap Operas“. International Review of Applied Linguistics 39: 39-50.

González-Lloret, M. 2010. "Conversation analysis and speech act performance". Speech Act Performance: Theoretical, Empirical and Methodological Issues. Eds. A. Martínez-Flor and E. Usó-Juan. Amsterdam: John Benjamins. 57-73.

Kasper, G. 2006a. "Beyond repair: Conversation analysis as an approach to SLA". Themes in SLA Research. AILA 19: 83-99. 
Kasper, G. 2006b. "Speech acts in interaction: Towards discursive pragmatics". Pragmatics and Language Learning 11: 281-314.

Kasper, G. and C. Roever, 2005. "Pragmatics in second language learning". Handbook of Research in Second Language Teaching and Learning. Ed. E. Hinkel. Mahwah, New Jersey: Lawrence Erlbaum Associates, Inc. 317-334.

Kondo, S. 2008. "Effects on pragmatic development through awareness-raising instruction: Refusals by Japanese EFL Learners". Pragmatics in Foreign Language Learning, Teaching and Testing. Eds. E. Alcón and A. MartínezFlor. Clevedon: Multilingual Matters. 153-177.

Kubota, M. 1995. "Teachability of conversational implicature to Japanese EFL learners". IRLT Bulletin 9: 35-67.

Martínez-Flor, A. 2007. "Analysing request modification devices in films: implications for pragmatic learning in instructed foreign language contexts". Intercultural Language Use and Language Learning. Eds. E. Alcón and M. P. Safont. Amsterdam: Springer. 245-280.

Martínez-Flor, A. 2008. "The effect of an inductive-deductive teaching approach to develop learners' use of request modifiers in the EFL classroom". Learning how to Request in an Instructed Language Learning Context. Ed. E. Alcón. Bern: Peter Lang. 192-225.

Martínez-Flor, A. 2011. "How to say 'no' politely: instructional effects in the ESP setting”. La Investigación y la Enseñanza Aplicadas a las Lenguas de Especialidad y a la Tecnología. Eds. M. L. Carrió, J. Contreras, F. Olmo, H. Skorczynska, I. Tamarit and D. Westall. Valencia: Universitat Politècnica de València. 357-363.

Martínez-Flor, A. 2012. "Examining EFL learners' long-term instructional effects when mitigating". Interlanguage Request Modification. Eds. M. EconomidouKogetsidis and $\mathrm{H}$. Woodfield. Amsterdam: John Benjamins Publishing Company. 243-274.

Martínez-Flor, A. 2013. "Learners' production of refusals: Interactive written DCT versus oral role-play“. Refusals in Instructional Contexts and Beyond. Eds. P. Salazar and O. Martí. Amsterdam: Rodopi.

Martínez-Flor, A. and E. Usó-Juan. 2006. A comprehensive pedagogical framework to develop pragmatics in the foreign language classroom: The 6Rs approach. Applied Language Learning 16 (2): 39-64.

Martínez-Flor, A. and E. Usó-Juan. 2010a "The teaching of speech acts in second and foreign language instructional context". Pragmatics Across Languages and Cultures. Ed. A. Trosborg. Berlin: Mouton de Gruyter. 423-442. 
Martínez-Flor, A. and E. Usó-Juan. 2010b. "Pragmatics and speech act performance". Speech Act Performance: Theoretical, Empirical and Methodological Issues. Eds. A. Martínez-Flor, and E. Usó-Juan. Amsterdam: John Benjamins. 3-20.

Martínez-Flor, A. and E. Usó-Juan, eds. 2010c. Speech Act Performance: Theoretical, Empirical and Methodological Issues. Amsterdam: John Benjamins.

Mohammad, G. Alireza, B. and M. Shirin. 2013. "Investigating cross-linguistic differences in refusal speech act among native Persian and English speakers". International Journal of Research Studies in Language Learning 2 (4): 49-63.

Rose, K. and C. Ng Kwai-fun, 2001. "Inductive and deductive approaches to teaching compliments and responses to compliments". Pragmatics in Language Teaching. Eds. K. R. Rose and G. Kasper. Cambridge: Cambridge University Press. 145-170.

Salazar, P., Safont, M. P. and V. Codina. 2009. "Refusal strategies: A proposal from a sociopragmatic approach”. Revista Electrónica de Lingüística Aplicada 8: 139150 .

Shaw, P. and A. Trosborg, 2000. "Sorry does not pay my Bills: Customer Complaints in a Cross Cultural Setting". Heritage and Progress. From the Past to the Future in Intercultural Understanding. Eds. L. Donald and A. Pilbeam. Bath: UK, LTS Training and Consulting in association with SIETAR Europa. 204-214.

Smith, C. 1998. Can Adult "just say no?": How Gender, Status, and Social Goals Affect Refusals. Unpublished Ph.D. thesis. University of South Florida, The United States.

Takimoto, M. 2008a. "The Effects of Various Kinds of Form-Focused Instruction on Learners' Ability to Comprehend and Produce Polite Requests in English". TESL Canada Journal 26 (1): 31-51.

Takimoto, M. 2008b. "The effects of deductive and inductive instruction on the development of language learners' pragmatic competence". The Modern Language Journal 92 (3): 369-386.

Tateyama, Y., Kasper, G., Mui, L., Tay, H. and O. Thananart. 1997. "Explicit and implicit teaching of pragmatics routines". Pragmatics and Language Learning 8: 163-177.

Trosborg, A. 2003. "The teaching of business pragmatics". Pragmatic Competence in Foreign Language Teaching. Eds. A. Martínez-Flor, E. Usó-Juan and A. Fernández-Guerra. Castellón: Servei de Publicacions de la Universitat Jaume I. 247-281. 
Usó-Juan, E. 2007. "The presentation and practice of the communicative act of requesting in textbooks: Focusing on modifiers“. Intercultural Language Use and Language Learning. Eds. E. Alcón and M. P. Safont. Amsterdam: Springer. 223-243.

Usó-Juan, E. 2008. “A pragmatic approach-focused evaluation of requests and their modification devices in textbook conversations". Learning how to Request in an Instructed Language Learning Context. Ed. E. Alcón. Bern: Peter Lang. 65-90.

Usó-Juan, E. and A. Martínez-Flor, 2006. “Approaches to language learning and teaching: Towards acquiring communicative competence through the four skills". Current Trends in the Development and Teaching of the Four Language Skills. Eds. E. Usó-Juan and A. Martínez-Flor. Berlin: Mouton de Gruyter. 3-25.

Wannaruk, A. 2008. Pragmatic transfer in Thai EFL refusals. RELCJournal 39 (3): 318-337.

Yagiz, O. 2009. "Turkish textbooks dialogues and comparable authentic conversations”. Atatürk Universitei Sosya Bilimler Enstitüsü Dergisi 13 (1): 217-225. 
APPENDIX A

\section{Film scenes taken from Crasb. ${ }^{1}$}

Situation 1: This is a conversation between the officer Ryan and Shaniquia Johnson who is an assistant at the network health. Ryan goes to the medical centre to talk to the assistance about a problem that his father has.

1. Assistant: Mr. Ryan.

2 Ryan: Yeah.

3. Assistant: My name is Shaniquia Johnson. I believed we spoke last night.

4. Ryan: Oh, yeah. I wanted to apologize about that. I haven't been sleeping much. My father's in a lot of pain.

5. Assistant: Oh, I'm sorry to hear that.

6. Ryan: This doctor says he's got a urinary tract infection. But he's been taken medicine for a month and keeps getting worse.

7. Assistant: And he's been back to see Dr. Robertson?

8. Ryan: Yeah. Between you and me, the man's an idiot.

9. Assistant: Really?

10. Ryan: No offense. But he sees 100 patients an hour. His nurses are doing his work.

11. Assistant: If you're unhappy your father's welcome to see a doctor outside the network.

12. Ryan: And if this new doctor says it's not an infection, and it needs to be operated on, is that gonna be covered?

13. Assistant: Not unless Dr. Robertson authorizes...

14. Ryan: What good is that gonna do?

15. Assistant: I'm sorry. There's nothing else I can do.

16. Ryan: You know what I can't do?

17. Ryan: [...] I can't help thinking on the white men who didn't get your job.

18. Assistant: It's time for you to go.

19. Ryan: And I'm hoping that I'm wrong about you. I'm hoping that someone like yourself, someone who may have been given a helping hand, might have a little compassion.

20. Assistant: Carol, I need security in my office!

\footnotetext{
1 In all the film scenes included in the Appendices, refusal semantic formulae are in italics for reader's quick identification.
} 
21. Ryan: You don't like me, that's fine. I'm a prick. My father doesn't deserve to suffer like this. He was a janitor. He struggled his whole life. He saved enough to start his own company: 23 employees, all of them black. Paid'em equal ways when no one else was doing that. [...] I'm not asking you to help me. I'm asking that you do this for a man who lost everything, so people like yourself could reap the benefits. And you know what it'sgonna cost you? Nothing. Just a flick of your pen.

22. Assistant: Your father sounds like a good man. And if he'd come in here today, I probably would've approved this request. But he didn't come in. You did. And for his sake, it's a real shame.

Situation 2: Jane and Rick, a married couple, have been attacked in the street by two Afro-American guys who have stolen their car. Later, at home, they report to the police what has happened. For security reasons, they also change the door locks.

1. Jane: I need to talk to you for a sec.

1. Rick: (To his college) Give me a minute right? Find Flanagan, will you? Now.

3. Assistant: Yes, sir.

4. Rick: Yes, honey?

5. Jane: I want the locks changed again.

6. Rick: Why don't you just go lie down? Have you checked on James? 


\section{APPENDIX B}

\section{Film scene taken from Crash.}

Situation 1: Farhad is having a telephone conversation with the secretary of the store in which Daniel works repairing locks. He replaces Farhad's lock and suggests him fixing the door. However, Farhad does not believe in him. Then, Farhad's store is destroyed and he believes that Daniel is the responsible.

1. Secretary: Sir, I spoke to our employee and he told you, you needed to repair the door.

2. Farhad: He say he fix the lock. You come here and see how fixed it is! [Farhad daughter is entering into the shop. Her mother is also there trying to clean a wall since some people broke into the shop and destroyed almost everything.]

3. Secretary: You're yelling again.

4 Farhad: I am not yelling! I'm upset! Yes I am. Yes. I want his name. Yes. I want his name! Give me his name!

5 Secretary:

6 Farhad: I want his name!

7 Secretary:

\section{Film scene taken from Prime.}

Situation 2: Dave is smarten up when he sees Q-tips and starts to use them to clean his ears. His girlfriend tries to joke about that fact.

1. Dave: Hey, I'm not trying to freak you out here...but these Q-tips are amazing.

2. Rafi: Guess what? You're freaking me out. What are you talking about?

3. Dave: We never had these growing up. I saw them in my mom's bathroom, but we never used them.

4. Rafi: How did you clean your ears?

5. Dave: Didn't. Just towel-dried them, I guess.

6. Rafi: Let me see the Q-tip.

7. Dave: 
APPENDIX C

Refusal responses in each situation from the two film scenes presented in Appendix B.

Situation 1

1. Secretary: I'm not giving you bis name.

2. Secretary: I'm gonna hang up now, sir.

Situation 2

1. Dave: No. You have to get out of here.

\section{APPENDIX D}

Data-collection sheet for examining refusal strategies, (adapted from MartínezFlor and Usó-Juan 2006: 52).

\begin{tabular}{l}
\hline Film data-collection sheet \\
Answer the following questions \\
1. Which strategies are employed? \\
2. Describe the participants in terms of gender and age. \\
3. Where are they? \\
4. Which is the role play by each participant? \\
5. Which status is represented by each participant? \\
6. How would you describe their relationship? \\
7. Which are participants' intentions? \\
\hline Select the option you think is suitable \\
1. Speakers' social distance: stranger, acquaintance and intimate \\
2. Speakers' power: S*>H** S=H S<H \\
3. Speakers' rank of imposition: low, equal and high \\
Recapitulating \\
1. How sociopragmatic features might affect pragmalinguistic realisations? \\
2. To which extend communicative purposes might not be achieved if \\
$\quad$ pragmalinguistic features are not realised accordingly to sociopragmatic \\
Note: *S= Speaker and **H=Hearer
\end{tabular}




\section{APPENDIX E}

\section{Film scene taken from The Constant Gardener.}

Situation 1: Tessa and Justin are going home after having been in the hospital. While they are on the road, Tessa sees a woman carrying a new-born baby, accompanied only by another child. They were also in the hospital and the mother of the baby died after having given birth.

1. Tessa: Justin, stop the car.

2. Justin: Why? What is it?

3. Tessa: Stop, stop, stop.

[Justin stops the car and sees from the side mirror that there is an African woman with a baby and a child]

4. Justin: Tessa.

5. Tessa: It's 40 kilometres to Miluri. It's gonna take them all night.

6. Justin: We shouldn't get involved in their lives, Tessa.

7. Tessa: Why?

[The car is locked, so she unlocks opens the doors since she wants to give them a lift to their place.]

8. Justin: Be reasonable. There are millions of people. They all need help. That's what the agencies are here for.

9. Tessa: Yeah, but these are three people that we can help.

10. Justin: Please.

11. Tessa: Justin.

12. Justin: I'm sorry, Tessa. I have to put you first. I have to get you home.

\section{Film scene taken from Prime.}

Situation 2: Dave and Morris are at Rafi's place having some beers when Dave hears the lift door. Rafi does not like having visitors at home. Dave tries to hide his friend in a closet.

1. Morris: Seriously, I barely even see you anymore. I mean, you even said it. I'm only here right now because she's not at home.

[Dave realises that the lift is opening.]

2. Dave: Oh, shit. It's her. Come on. You got to hide.

3. Morris: Are you serious? I really can't be bere?

4. Dave: Yeah. No. Get in the closet. Get in the closet. Get in the closet.

5. Morris: The closet? Man, what's...? 
6. Dave: She doesn't like people in her living space.

[Dave takes him and accompanies Morris to the closet.]

7. Morris: Living space? What the bell's living space? All right, is the kitchen part of it?

8. Dave: Just get in the closet.

9. Morris: Jesus Christ.

[He gets into the closet.]

[Rafi is at home.]

10. Dave: Hey. What are you doing home already?

11. Rafi: Oh, I'm sorry. Would you like me to leave?

I thought you were hanging out with Morris today?

\section{APPENDIX F}

Retrospective verbal probe (adapted from Félix-Brasdefer 2008a: 71-72; 2008b: 200).

\begin{tabular}{|l|}
\hline Interview with participants \\
Participant $A$ \\
\hline Which aspects did you pay attention to when performing this situation? \\
\hline Did you find any difficulties when performing the situation? \\
\hline Was your performance influenced by any aspect of the context? \\
\hline $\begin{array}{l}\text { Interview with participants } \\
\text { Participant } B\end{array}$ \\
\hline Which aspects did you pay attention to when performing this situation? \\
\hline Did you find any difficulties when performing the situation? \\
\hline Was your performance influenced by any aspect of the context? \\
\hline
\end{tabular}

